\title{
Differences in properties in respirational physiology among some chironomid species of the genus Polypedilum
}

\author{
Koichiro KAwAI ${ }^{1)}$, Satomi HAyASHI ${ }^{2)}$ and Hiromichi ImABAYASHI ${ }^{1)}$ \\ 1) Laboratory of Ecology, Faculty of Applied Biological Science, Hiroshima University, Kagamiyama 1-4-4, \\ Higashihiroshima, 739-8528 Japan \\ 2) Zeneka Pharmaceuticals Co., Ltd., Oyodonaka 1-1-88, Kita-ku, Osaka, 531-0076 Japan
}

(Received: 17 November 1999; Accepted: 27 June 2000)

Key words: anaerobic resistance, chironomid larvae, Hb, oxygen consumption, Polypedilum, survival

\begin{abstract}
Five chironomid species of the genus Polypedilum were examined for their larval oxygen consumption rates, survival in anaerobic conditions, and contents and compositions of $\mathrm{Hb}$ by laboratory experiments. They showed different respirational properties in accordance with their respective habitat conditions. The mean oxygen consumption rate was the highest for P. masudai, an oligotrophic lake species, and the lowest for $P$. nubifer, an eutrophic lake species. The mean survival rate of $P$. asakawaense, another species from oligotrophic waters, was decreased to about $10 \%$ within 10 hrs after anaerobic exposure whereas that of $P$. nubifer remained about $15 \%$ even $40 \mathrm{hrs}$ after exposure. Fifty \% survival time was the longest for P. nubifer and the shortest for P. asakawaense. P. masudai had a similar Hb pattern to P. japonicum in PAGE. None of the other 3 species showed a similar pattern to the former two species, and remarkable differences were observed among the 3 species. Some Hb bands were common to two to all species whereas some were specific to a particular species. $\mathrm{Hb}$ contents under the rearing condition of $0.4 \%$ milk-containing agar were about twice and 1.4 times higher than those under the condition of $0.08 \%$ milk for P. asakawaense and for $P$. nubifer, respectively. Hb content under the condition of $2 \%$ milk was lower than those under the conditions of 0.08 and $0.4 \%$ milk for P. cultellatum. Some $\mathrm{Hb}$ bands appeared with the increase of milk content for all 3 species examined, suggesting their roles in an efficient transportation of oxygen molecules from oxygen-poor environments.
\end{abstract}

\section{INTRODUCTION}

Chironomid larvae of the genus Polypedilum are known to live in a wide variety of inland waters (Wiederholm, 1989; Sasa and Kikuchi, 1995), and there are remarkable differences in environmental requirements among the species for various factors (Beck, 1977; Kawai et al., 1998; 1999b). Thus, physiological properties of larvae are considered to differ from species to species. However, there have been practically no reports on such properties, especially on those in respirational physiology, among the species of this genus.

In this study, larvae of some species, widely distributed in Japan, were examined for their oxygen consumption rates, survival in anaerobic conditions, and contents and compositions of $\mathrm{Hb}$ by laboratory rearing experiments. The differences in these properties among the species were discussed in relation to eutrophication levels of their habitat waters.

$$
\text { Materials AND Methods }
$$

\section{Chironomids and rearing method Larvae of Polypedilum cultellatum and $P$.}


nubifer were obtained by laboratory culture as described in Kawai et al. (1999a) and Kawai and Muraguchi (1998), respectively. Those of P. asakawaense, P. japonicum and $P$. masudai were obtained by rearing the 1st instar larvae hatching from fertilized egg masses laid by female adults captured in the field.

For rearing experiments, a milkcontaining agar medium, described in Shirota (1969), was used as follows. Newly hatched larvae of each species were reared at a density of 100 individuals per plastic container $(\phi 15 \times 9 \mathrm{~cm})$ at room temperature. Each container was layered with 200 $\mathrm{ml}$ of $1 \%(\mathrm{w} / \mathrm{v})$ agar containing $2 \%(\mathrm{v} / \mathrm{v})$ milk (fat content $3.5 \%$ ) at the bottom, filled with $600 \mathrm{~m} l$ of dechlorinated water, and aerated through an airstone. As the material for the tube (or case) building, 50 $\mathrm{m} l$ of glass beads $(0.1 \mathrm{~mm}$ in diameter) was spread on the agar plate. In some cases, $1 \%$ agar media containing $0.08,0.4$ or $10 \%$ milk were used as different rearing conditions in the eutrophication level.

\section{Oxygen consumption rate and survival in an anaerobic condition}

Oxygen consumption rate was measured with a BOD bottle (Sibata Scientific Technology Ltd., Tokyo, Japan) of approximately $100 \mathrm{~m} l$ in volume. Ten to 50 individuals of the 4 th instar larvae of each species were put in the bottle at $25^{\circ} \mathrm{C}$ which was filled with water saturated with oxygen by air bubbling and spread with $10 \mathrm{ml}$ of glass beads. A bottle without larvae was also incubated at $25^{\circ} \mathrm{C}$ as control. Three hours later, dissolved oxygen concentration in the water was measured by Winkler's method (Alsterburg, 1925). Oxygen consumption rate $(\mu \mathrm{g}$. $\mathrm{hr}^{-1} \cdot \mathrm{mg}$ wet larvae ${ }^{-1}$ ) was calculated from the difference in the amount of dissolved oxygen between the control bottle and the sample bottle. The experiments were performed 6-11 times for each species.

Survival in an anaerobic condition was examined by the method described by Hi- rabayashi and Hayashi (1994). In brief, five to 15 individuals of the 4 th instar larvae of each species were put in the BOD bottle in which dissolved oxygen had been almost completely driven out $(<0.5 \mathrm{mg}$ $\mathrm{O}_{2} / \mathrm{L}$ ) by bubbling of nitrogen air. Survival was observed until all the individuals died. Death was judged as a lack of undulational behaviour, no response to physical stimuli, and/or changes in body shape and color. Time for 50\% survival was estimated on the basis of survival curves. The experiments were performed 3-13 times for each species.

\section{Ho analyses}

Total $\mathrm{Hb}$ was prepared by homogenization of larvae in a small amount of distilled water, followed by centrifugation of the homogenate at $13,000 \mathrm{rpm}$ for $10 \mathrm{~min}$ at $4^{\circ} \mathrm{C}$ and lyophilization of the supernatant. $\mathrm{Hb}$ components were separated by polyacrylamide gel electrophoresis (PAGE), on the basis of Laemmli (1970), with some modifications. The total $\mathrm{Hb}$ was mixed with a sample buffer, $\mathrm{pH}$ 6.8, without 2-mercaptoethanol, and electrophoresed at $30 \mathrm{~mA}$ for $2 \mathrm{hrs}$. The gel plate was composed of a stacking gel (4\% acrylamide in $0.125 \mathrm{M}$ Tris- $\mathrm{Cl}, \mathrm{pH}$ 6.8) and a separation gel (15\% acrylamide in 0.375 MTris-Cl, pH8.8). After running, the gel was stained with a DAB buffer (Merck, Darmstadt, Germany) using benzidin reaction.

Total $\mathrm{Hb}$ content was measured by the cyanmethemoglobin method (van Assendelft and Zijlstra, 1975) using Nescort hemokit-N (Nihon Shoji, Co., Ltd., Osaka, Japan) as a standard solution.

\section{Statistical analysis}

Significance of the differences in the mean values among the species was assessed by the $t$-test.

\section{RESULTS}

Oxygen consumption rate and survival in an anaerobic condition 


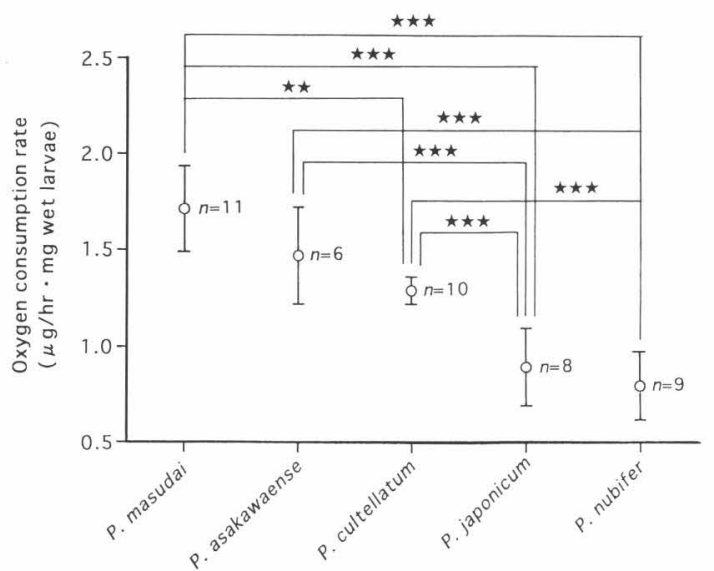

Fig. 1. Comparison of oxygen consumption rates among 5 species. $n$ means the number of experiments. Open circles represent the mean rates, and vertical bars represent standard deviations. $\star \star \star, P<0.01 ; \star \star \star, P$ $<0.001$

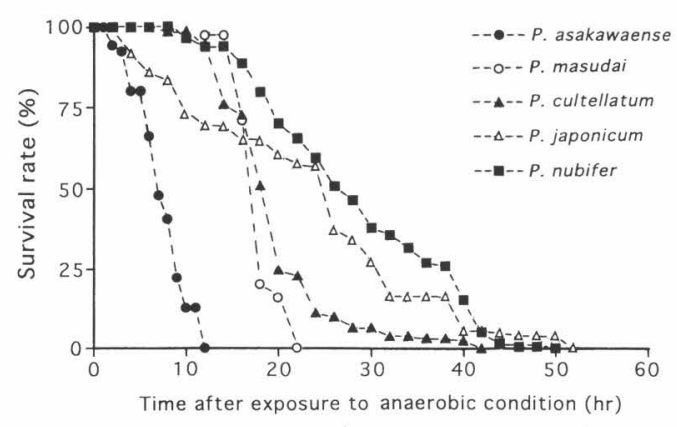

Fig. 2. Comparison of survival curves under an anaerobic condition among 5 species. Symbols represent the mean rates of multiple experiments.

The mean oxygen consumption rate was the highest for $P$. masudai and the lowest for $P$. nubifer (Fig. 1). The mean rate differed significantly in all combinations except between $P$. masudai and $P$. asakawaense, between $P$. asakawaense and $P$. cultellatum and between $P$. japonicum and $P$. nubifer.

Four patterns of survival curves were observed (Fig. 2). In the first pattern as for $P$. asakawaense, the mean survival rate was drastically decreased to about 10\% within only $10 \mathrm{hrs}$ after exposure to an anaerobic condition. In the second pattern as for P. japonicum, it was gradually de-

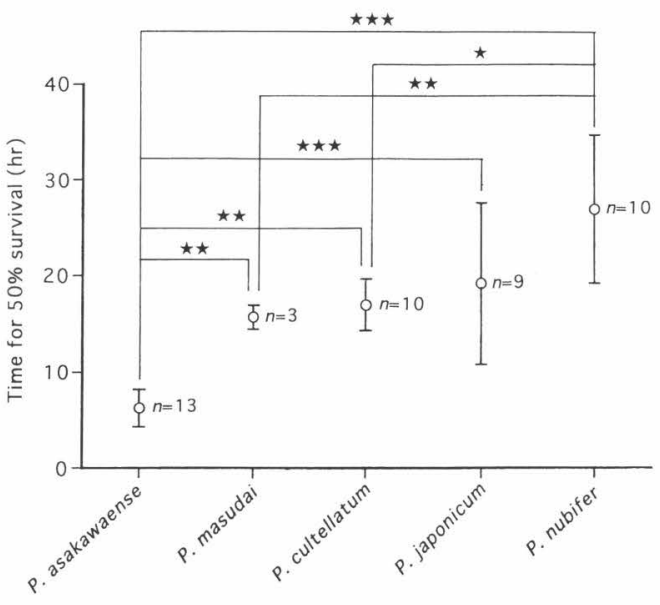

Fig. 3. Comparison of time for $50 \%$ survival under an anaerobic condition among 5 species. $n$ means the number of experiments. Open circles represent mean times, and vertical bars represent standard deviations.

$\star, P<0.05 ; \star \star, P<0.01 ; \star \star \star, P<0.001$

creased to about $25 \%$ within $30 \mathrm{hrs}$. In the third pattern as for P. masudai and P. cultellatum, it remained high upto $12-14 \mathrm{hrs}$ and abruptly decreased to about 25\% within $20 \mathrm{hrs}$. In the fourth pattern as for $P$. nubifer, it began to gradually decrease about 12 hrs after the exposure and remained about $15 \%$ even $40 \mathrm{hrs}$ after the exposure.

Time for 50\% survival in anaerobic condition was the longest for $P$. nubifer and the shortest for $P$. asakawaense (Fig. 3). That for $P$. nubifer was significantly longer than those of other species except $P$. japonicum. Those for P. japonicum, $P$. cultellatum and $P$. masudai were significantly longer than that of $P$. asakawaense.

Differences in $\mathrm{Hb}$ compositions among the species

Polypedilum masudai showed a similar $\mathrm{Hb}$ pattern to that of $P$. japonicum in PAGE analysis. The other 3 species showed quite different $\mathrm{Hb}$ patterns from the former two species. Further, there were remarkable differences in patterns among the latter 3 species (Fig. 4).

Some $\mathrm{Hb}$ bands were common to different species. The band 16 was common to 


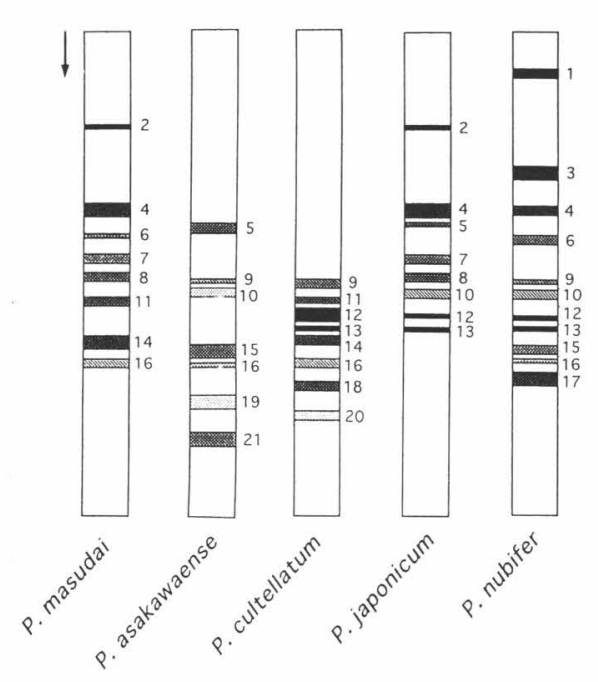

Fig. 4. Comparison of $\mathrm{Hb}$ compositions among 5 species by PAGE. Each $\mathrm{Hb}$ band was numbered from the origin to the front.

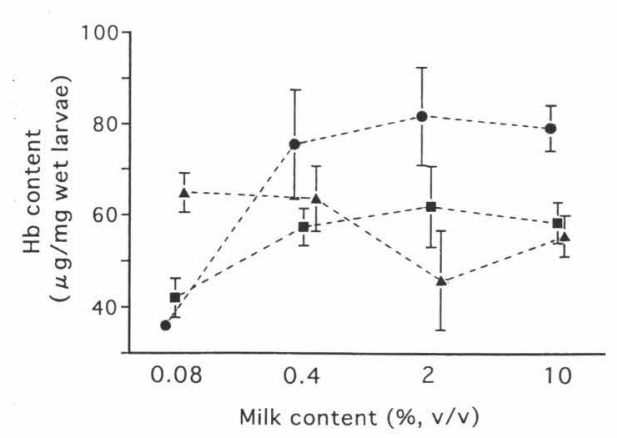

Fig. 5. Effect of milk contents in agar media on $\mathrm{Hb}$ contents of 3 species. $P$. asakawaense; $\mathbf{\Delta}$, P. cultellatum; $\mathbf{\square}$, P. nubifer

all species except for $P$. japonicum. The bands 4, 9 and 10 were common to $P$. masudai, $P$. japonicum and $P$. nubifer; $P$. asakawaense, $P$. cultellatum and $P$. nubifer; and $P$. asakawaense, $P$. japonicum and $P$. nubifer, respectively. The bands 12 and 13 were common to P. cultellatum, P. japonicum and $P$. nubifer. The bands 2, 7 and 8 were common to $P$. masudai and $P$. japonicum. The band 5, 6 and 15 were common to $P$. asakawaense and $P$. japonicum; $P$. masudai and $P$. nubifer; and $P$. asakawaense and $P$. nubifer, respectively. The bands 11 and 14 were common to $P$. $m a$ sudai and $P$. cultellatum. On the other hand, some bands were species-specific. The bands 1,3 and 17 were specific to $P$. nubifer. The bands 18 and 20; and 19 and 21 were specific to $P$. cultellatum and $P$. asakawaense, respectively.

\section{Effects of milk content in agar on $\mathrm{Hb}$ content and $\mathrm{Hb}$ composition}

To examine the effects of water deterioration on chironomid $\mathrm{Hb}$, rearing experiments were performed under different conditions in milk content. For this purpose, three species, $P$. asakawaense, $P$. cultellatum and $P$. nubifer, were selected on the basis of the remarkable differences in the survival curve in an anaerobic condition among these 3 species.

For $P$. asakawaense, $\mathrm{Hb}$ content under the rearing condition with agar media containing $0.4 \%$ milk was about twice higher than that under the condition with agar media containing $0.08 \%$ milk (Fig. 5). However, no remarkable differences in $\mathrm{Hb}$ content were observed among the conditions of $0.4,2$ and $10 \%$ milk. Similar results were obtained for $P$. nubifer. $\mathrm{Hb}$ content under the condition of $0.4 \%$ milk was about 1.4 times higher than that under the condition of $0.08 \%$ milk. For $P$. cultellatum, in contrast, $\mathrm{Hb}$ contents under the conditions of 2 and $10 \%$ milk were lower than those under the conditions of 0.08 and $0.4 \%$ milk.

Remarkable differences in $\mathrm{Hb}$ compositions were observed among the 4 different rearing conditions in milk content for any of three species (Fig. 6). For P. asakawaense, the band 10 appeared under the conditions of $0.4,2$ and $10 \%$ milk. The band 21 appeared under the conditions of 2 and $10 \%$ milk. For P. cultellatum, the bands 14 and 15 appeared under the conditions of 2 and $10 \%$ milk, respectively. For $P$. nubifer, the band 1 appeared under the conditions of 2 and $10 \%$ milk while the band 15 appeared on the conditions of $0.4,2$ and 10\% milk.

\section{Discussion}

The genus Polypedilum is a large one, comprising many species, and is dis- 
P. asakawaense

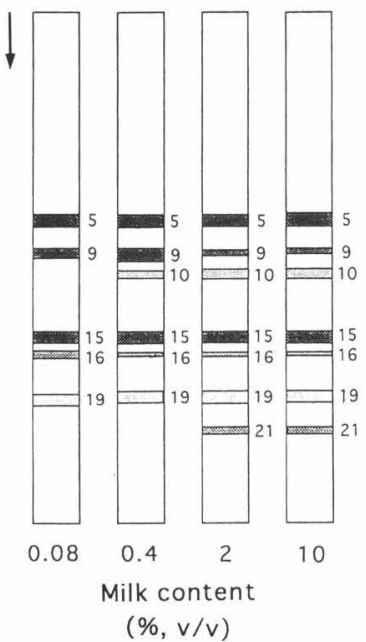

P. cultellatum

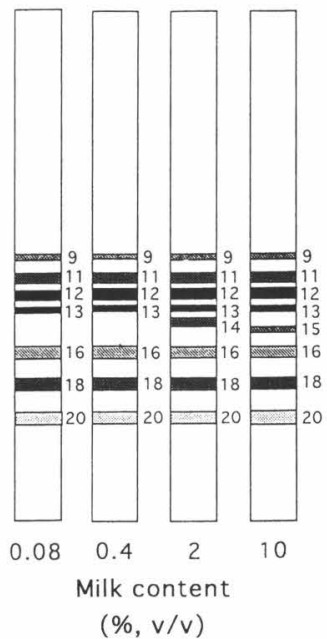

P. nubifer

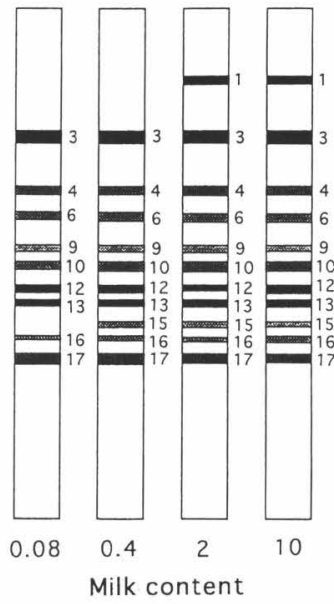

$(\%, v / v)$

Fig. 6. Effects of milk contents in agar media on $\mathrm{Hb}$ compositions of 3 species.

tributed in a wide range of eutrophication levels (Sasa and Kikuchi, 1995) and it has been suggested that there are some habitat-segregations among the species in relation to various environmental factors (Kawai et al., 1998), probably based on the differences in physiological properties. In this study, remarkable differences were shown among 5 species of this genus for all the respirational properties examined. The physiological properties of chironomid larvae will be related to the eutrophication level of their habitat waters. The oxygen consumption rate was the highest to the lowest in the following order: $P$. masudai $>P$. asakawaense $>P$. cultellatum $>$ P. japonicum $>$ P. nubifer. Survival in an anaerobic condition was high in the following order: $P$. nubifer $>P$. japonicum $>P$. cultellatum $>P$. masudai $>P$. asakawaense when evaluated from 50\% survival time. These orders correspond to the eutrophication level of their habitats. Namely, the species from oligotrophic habitats have high oxygen consumption rate and low resistance to an anaerobic condition, and those from eutrophic habitats have the opposite tendency. Sasa (1985) has collected $P$. masudai from Lake Ikeda, which is an oligotrophic lake (Yasuno et al., 1983). P. asakawaense has been collected in the highest frequency from waters of $1>$ in $\mathrm{BOD}$ value whereas $P$. japonicum has been collected in the highest frequency from waters of $2-3$ in BOD value (Kawai et al., 1989). P. cultellatum and $P$. nubifer have been collected in large numbers from an eutrophic lake, Lake Kasumigaura (Ueno et al., 1993). In addition, the differences in anaerobic survival among the species may result from the mechanism and efficiency of anaerobic metabolism, i.e., glycolytic system.

The composition of $\mathrm{Hb}$ components does not necessarily reflect the evolutionary relationships between the species. That is, $P$. japonicum and $P$. masudai, both belonging to the same subgenus Tripodula, showed a similar PAGE pattern of $\mathrm{Hb}$ whereas $P$. asakawaense and $P$. nubifer, also both belonging to the same group of the subgenus Polypedilum, apparently showed quite a different $\mathrm{Hb}$ pattern from each other. The $\mathrm{Hb}$ composition of a species may be determined not only by evolutional factors but also by environmental factors. However, some $\mathrm{Hb}$ components, i.e., bands $1,3,17,18,19,20$ and 21 , were shown to be species-specific, and these components or their genes can be applied to enable rapid and correct identification at larval stages. 
In some littoral chironomid species, $\mathrm{Hb}$ contents have been reported to increase with depth in the sediments of their habitats, due to an adaptation to a low concentration of dissolved oxygen at the depth of sediments (Panis et al., 1996). In this study, however, $\mathrm{Hb}$ content was much higher in shallow dwelling species $P$. $a s a$ kawaense than in deeper dwelling species $P$. nubifer, except for under the rearing condition of $0.08 \%$ milk. This suggests that chironomid larvae can be a dweller of deep habitats in sediments not only by the increase of $\mathrm{Hb}$ content but also by the change in $\mathrm{Hb}$ composition.

Differences in the eutrophication level in the rearing water affected larval $\mathrm{Hb}$ contents of $P$. asakawaense and $P$. nubifer. That is, $\mathrm{Hb}$ content under the condition of agar containing $0.4 \%$ milk was about twice higher than that under the condition of $0.08 \%$ milk for $P$. asakawaense. Similarly, $\mathrm{Hb}$ content under the condition of $0.4 \%$ milk was about 1.4 times higher than that under the condition of $0.08 \%$ milk for $P$. nubifer. These results indicate an adaptation of larvae to deterioration of water quality by increasing $\mathrm{Hb}$ contents in their body fluid. The range of changes in $\mathrm{Hb}$ contents was wider in the former species than in the latter. A possible explanation for this may be as follows. $P$. nubifer larvae had adapted to relatively oxygen-poor conditions by nature whereas $P$. asakawaense larvae had adapted to relatively oxygen-rich conditions. Thus, the $\mathrm{Hb}$ contents of $P$. nubifer larvae are considered not to be strongly influenced by a change in the eutrophication level. On the other hand, $\mathrm{Hb}$ contents of P. cultellatum larvae slightly decreased with progress of eutrophication. This species has been observed to dwell in an interface zone between air and the water surface where algal film is well developed, and it has been collected almost exclusively from water plant zones in the lake (Ueno et al., 1993). Therefore, this species may be able to efficiently utilize dissolved oxygen produced by algae or other plants. Thus,
P. cultellatum larvae have adapted to water deterioration differently (e.g., behaviourly) from the other two species.

Compositions of $\mathrm{Hb}$ differed among four different eutrophication levels of rearing water for any species. The Hb bands 1,10 , 14, 15 and 21 appeared under more eutrophicated conditions at least for a species. The number of $\mathrm{Hb}$ bands of Chironomus ramosus has been reported to increase as larval stage progressed (Das and Handique, 1996). Besides, young larvae of $C$. anthracinus showed 50\% of mortality 3 days after exposure to anoxia as compared to only $25 \%$ of mortality even $3-4$ weeks after the exposure for older larvae (Hamburger and Lindegaard, 1995). These results suggest that some of $\mathrm{Hb}$ bands 1, 10, 14, 15 and 21 of Polypedilum larvae in this study have an important role in efficient intake of dissolved oxygen from oxygen-poor water environments. Purification and examination of affinity to oxygen should be undertaken for these $\mathrm{Hb}$ components.

\section{REFERENCES}

Alsterburg, G. (1925) Methoden zur Bestimmung von in Wasser gelosten elementaren Sauerstoff bei Gegenwart von salpetriges Saure. Biochem. Z., 159: 36-47.

Beck, M. W. (1977) Environmental Requirements and Pollution Tolerance of Common Freshwater Chironomidae, 261 pp., Environmental Monitoring and Support Laboratory, U. S. Environmental Protection Agency, Cincinnati.

Das, R. and R. Handique (1996) Hemoglobin in Chironomus ramosus (Insecta, Diptera): an electrophoretic study of polymorphism, developmental sequence and intraspecific relationship. Hydrobiologia, 318: 43-50.

Hamburger, K., P. C. Dall and C. Lindegaard (1995) Effects of oxygen deficiency on survival and glycogen content of Chironomus anthracinus (Diptera, Chironomidae) under laboratory and field conditions. Hydrobiologia, 297: 187-200.

Hirabayashi, K. and H. Hayashi (1994) Horizontal distribution of benthic macroinvertebrates in Lake Kizaki, Japan. Jpn. J. Limnol., 55: 105-114. 
Kawai, K., S. Hayashi and H. Imabayashi (1999a) A comparison of the $N$-terminal sequence of the corresponding hemoglobin component between closely related chironomid species, Polypedilum nubeculosum and P. nubifer. Med. Entomol. Zool., 50: 251255.

Kawai, K., E. Inoue and H. Imabayashi (1998) Intrageneric habitat segregations among chironomid species of several genera in river environments. Med. Entomol. Zool., 49: 41-50.

Kawai, K., E. Inoue and H. Imabayashi (1999b) Differences in occurrence patterns in relation to three environmental factors among the lotic chironomid species of a genus, Polypedilum. Med. Entomol. Zool., 50: 233-242.

Kawai, K. and A. Muraguchi (1998) Gene cloning of a monomeric hemoglobin of a widely distributed chironomid Polypedilum nubifer. Hydrobiologia, 368: 91-99.

Kawai, K., T. Yamagishi, Y. Kubo and K. Konishi (1989) Usefulness of chironomid larvae as indicators of water quality. Jpn. J. Sanit. Zool., 40: 269283.

Laemmli, U. K. (1970) Cleavage of structural proteins during the assembly of the head of bacteriophage T4. Nature, 227: 680-685.

Panis, L. I., B. Godeeris and R. Verheyen (1996) On the relationship between vertical microdistribution and adaptation to oxygen stress in littoral Chironomidae (Diptera). Hydrobiologia, 318: 61-67.

Sasa, M. (1985) Studies on the chironomids collected from lakes in Southern Kyushu (Diptera, Chironomidae). Res. Rep. Natl. Inst. Environ. Stud., 83: 2599.

Sasa, M. and M. Kikuchi (1995) Chironomidae of Japan. 333 pp., Univ. Tokyo Press, Tokyo.

Shirota, A. (1969) Studies on "Akamushi”, 148 pp., Koseishakoseikaku, Tokyo (in Japanese).

van Assendelft, O. W. and W. G. Zijlstra (1975) Extinction coefficients for use in equations for the spectrophotometric analysis of haemoglobin mixtures. Anal. Biochem., 69: 43-48.

Ueno, R., T. Iwakuma and S. Nohara (1993) Chironomid fauna in the emergent plant zone of Lake
Kasumigaura, Japan. Jpn. J. Limnol., 54: 293-303.

Yasuno, M., T. Iwakuma, Y. Sugaya and M. Sasa (1983) Benthos in Japanese lakes at different trophic levels. In: Chironomids as indicator organisms of environment, B182-R12-17 (ed., Yasuno, M.), pp. 2148, Ministry of Education, Science and Culture of Japan, Tokyo (in Japanese).

Wiederholm, T. (ed.) (1989) Chironomidae of the Holarctic region. Keys and diagnoses. Part 3 -Adult males. Entomol. Scand. Suppl., 34: 1-532.

\section{摘要}

Polypedilum 属ユスリカ数種の呼吸生理学的特性 の違い

河合幸一郎 ${ }^{1)}$ 林 里実 ${ }^{2)}$ 今林博 道 ${ }^{1)}$

1) 広島大学生物生産学部動物生態学研究室 （干739-8528 東広島市鏡山 1-4-4）

2) ゼネ力薬品株式会社

（干531-0076 大阪市北区大淀中 1-1-88）

Polypedilum 属ユスリカ幼虫 5 種について, 室内飼育 実験により，その酸素消費量，嫌気条件下での生残及び へモグロビン $(\mathrm{Hb})$ の含量と組成を調べた。 その結果, 酸 素消費量の平均值はP. masudai が最も高く, P. nubifer が最も低かった。嫌気条件下での生残率はP. asakawaense では 10 時間後に約 $10 \%$ まで低下したのに対し， P. nubifer では 40 時間後でさえまだ 15\% であった。 $50 \%$ 生残時間は P. nubifer で最も長く, P. asakawaense で最も短かった， Hb の PAGE 解析ではP. masudaiの パターンはP. japonicum のそれにかなり類似していた が，他の 3 種はこれら 2 種に類似した組成は示さず，し かもこの3 種の間に著しい違いが見られた， $\mathrm{Hb}$ バンド のうちのあるものはそれぞれ 2 種から全種に共通であ り,あるあのは特定の 1 種に特異的であった. $0.4 \%$ 牛 乳を含む寒天培地を用いた飼育条件下では, $\mathrm{Hb}$ 量は 0.08\% でのそれに比べて, P. asakawaense よP.nubiferで，それぞれ 1.4 倍及び 2 倍に増加した。，一方， P. cultellatum では, $2 \%$ 牛乳を含む寒天培地では, $\mathrm{Hb}$ 量は 0.08 および $0.4 \%$ でのそれらに比べて低下した。 さらに，いずれの種の場合であ，あるバンドは培地の牛 乳含有量の増加に伴って現れる傾向を示し, これは, こ れらの Hb が酸素の乏しい条件下で効率良く酸素を輸送 する役割を担っていることを示唆すると考えられた. 